\title{
REMOVAL OF METAL IONS FROM BÍO BÍO RIVER WATER BY LIQUID-PHASE POLYMER-BASED RETENTION TECHNIQUE
}

\author{
*EDUARDO D. PEREIRA ${ }^{1}$, DANIELA HOMPER ${ }^{1}$, JULIO SÁNCHEZ², BERNABÉ L. RIVAS \\ ${ }^{1}$ Department of Analytical and Inorganic Chemistry, Faculty of Chemistry, University of Concepción, Concepción, Chile. \\ ${ }^{2}$ Polymer Department, Faculty of Chemistry, University of Concepción, Casilla 160-C, Concepción, Chile.
}

\begin{abstract}
Water-soluble poly(2-acrylamidoglycolic acid) (PAAG) was synthesized by radical polymerization and characterized by FTIR spectroscopy and potentiometric titration. Subsequently, this polymer was used as extracting reagent of metal ions using LPR technique, through washing and enrichment methods. By the washing method, the selective retention (100\%) of $\mathrm{Al}^{3+}$ was obtained at $\mathrm{pH} 2.36$. The removal of monovalent and divalent ions was maximum for all the metal ions at $\mathrm{pH} 5$.

The maximum retention capacity of some metal ions by PAAG was studied by enrichment method using water of Bío Bío river containing metal ions. The higher retention percentage for $\mathrm{Al}^{3+}$ ion indicates that PAAG could be used as an extracting reagent for $\mathrm{Al}^{3+}$ ions from Bío Bío river samples.
\end{abstract}

Keywords: Bío Bío river, Metal ions, Ultrafiltration, Membranes.

\section{INTRODUCTION}

In water sources, the metal ion pollutants may be concentrated, diluted o transported through of hydrologic cycle, affecting finally domestic waters. From of toxic point of view, metals are not biodegradables and therefore are accumulated in the living organisms exerting toxic actions [1-3].

Some of the heavy metals are among the most harmful of the elemental pollutant. These elements include essential elements like iron as well as toxic metals like lead, cadmium, and mercury. Most of them have a great affinity for sulfur and attack sulfur bonds in enzymes, thus immobilizing the enzymes. Carboxylic acid and amino groups of proteins are also chemically bound by heavy metals. Cadmium, copper, lead, and mercury ions bind to cell membranes, hindering transport processes through the cell wall. Heavy metals may also precipitate phosphate biocompounds or catalyze their decomposition [4-6].

Aluminum is the most abundant metal naturally present in air, soil, and water. Therefore, environmental exposure to aluminum is potentially possible. Particularly, it is believed that aluminum is responsible of several diseases that are related with neuronal damaged $[7,8]$. It enters to the brain and may contribute to Alzheimer's disease and other neurodegenerative diseases [9]. Aluminum is also able to give rise to toxicity in the bones and hematopoietic system in humans [10]. This fact has increased the interest for study the aluminum content and possible removal from domestic waters sources.

One of the most promising techniques for solve this problem is the application of separation methods based on membrane process $[11,12]$. In comparison with conventional systems for water and wastewater treatment, these have several advantages, such as easy operation and control, few chemical additives are used in the process, and costs of operating and maintenance are low [12].

Recently, the separation of toxic inorganic species has been investigated by a hybrid method using membranes coupled to water-soluble functional polymers [13]. This method is known as the liquid-phase polymer-based retention (LPR) technique [12-22]. In the LPR, a water-soluble polymer solution and metal ion solution are contacted on the feed-side in a filtration system. The polymer interacts with metal ions and these are bonded to the polymer resulting in polymer-metal macromolecules, which are then retained mainly by a size exclusion mechanism; whereas unbound species, with a diameter smaller than membrane cut-off diameter, pass through the membrane into the permeate stream [12]. The great advantage of the LPR method is that it is performed in homogeneous media and largely avoids the phenomenon of mass transfer or diffusion that occurs with heterogeneous methods [16]. Through LPR, it is possible to separate a series of metal cations, as well as toxic inorganic anions such as arsenates and chromates from aqueous solution [13]. However, just few examples related to aluminum removal from aqueous solution by LPR-washing method are described in the literature $[21,22]$.

Bío Bío river, located at the south of Chile between $36^{\circ} 45 \mathrm{~S}$ and $39^{\circ} \mathrm{S}$, is one of the most important Chilean rivers. Its main characteristics are 380 $\mathrm{km}$ length a basin of $24,260 \mathrm{~km}^{2}, 800,000$ people and medium flows between 200 and $1,600 \mathrm{~m}^{3} / \mathrm{h}$. Several economic activities, such as agriculture, forestry, energy generation, industries, tourism, recreation, and water supply are supported by its water resources.
The aim of this paper is to use poly(2-acrylamidoglycolic acid) (PAAG) as polychelatogen on LPR technique to remove metal ions. The effect of $\mathrm{pH}$ on the removal was analyzed by washing method. The enrichment mode was used for remove the aluminum metal ions from Bío Bío river waters.

\section{EXPERIMENTAL}

2.1 Synthesis of the poly(2-acrylamidoglycolic acid) (PAAG)

Although the synthesis of PAAG has been reported by the authors [23], the experimental conditions for this specific work are detailed because the amount of reagent used is different.

2-acrylamidoglycolic acid (Aldrich) and the metal ions standard solution (Merck) were used as received. The radical polymerization was carried out using $0.061 \mathrm{~mol}(10 \mathrm{~g})$ of 2-acrylamidoglycolic acid (AAGA) and $0.0012 \mathrm{~mol}$ $(0.2798 \mathrm{~g})$ of ammonium persulfate (APS) under nitrogen. The polymerizing mixture was kept at $60^{\circ} \mathrm{C}$ for $24 \mathrm{~h}$ in a polymerization flask. Subsequently, the product was purified by dissolving in water and passing through the ultrafiltration membrane with a molecular mass cut-off $100 \mathrm{kDa}$. The final product was lyophilized and characterized. The structure of PAAG is presented in figure 1 .

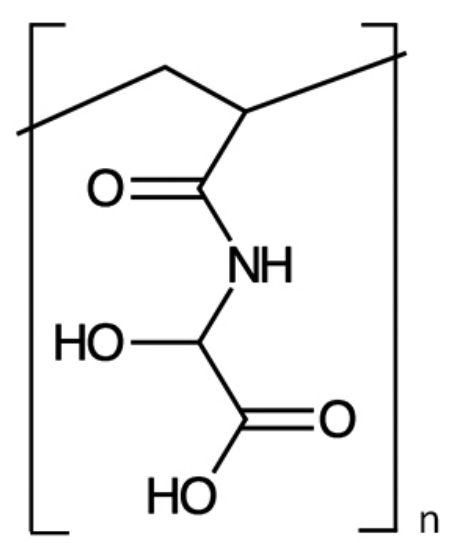

Figure 1. Chemical structure of PAAG

\subsection{Characterization of PAAG}

2.2.1 Fourier transform-infrared (FT-IR) spectroscopy

In order to ensure that the polymerization and purification method was correctly performed, the characterization of polymer was carried out by FT-IR spectroscopy. The FT-IR studies were performed in the range of $400-4000 \mathrm{~cm}^{-1}$ for both cases. FT-IR was performed using a Magna Nicolet 550 and Nexus Nicolet spectrometers. For quantitative analysis, $1 \mathrm{mg}$ of the sample per 100 $\mathrm{mg}$ of $\mathrm{KBr}$ was employed. 


\subsubsection{Potentiometric titration}

$20 \mathrm{~mL}$ of the main fraction of PAAG solution prepared at a concentration of $5.0 \mathrm{mM}$ was titrated with $5.0 \mathrm{mM} \mathrm{NaOH}$ solution. A pH-meter immersed in the polymer solution was used to measure the changes of $\mathrm{pH}$ by increasing the volume of added base. The $\mathrm{NaOH}$ was previously standardized with potassium hydrogen phthalate. The whole process is performed in triplicate.

\subsection{LPR Procedure}

When metal ions and the poly(2-acrylamidoglycolic) are placed in contact and diafiltered by ultrafiltration, the metal ions are retained, whereas ions with low interaction rates pass through the membrane to the permeate stream.

The main features of the LPR system include a filtration cell (Amicon 8050) with a magnetic stirrer that contains a membrane filter of polyethersulfone with a molecular weight cut-off (MWCO) of $10 \mathrm{kDa}$ (Millipore), a reservoir (Amicon RC800), a flow selector and a nitrogen gas cylinder as the pressure source. The detailed description of the system was presented previously [12].

Two types of experiments were investigated for the LPR technique.

2.3.1 Washing Method

In the washing a liquid sample containing water-soluble polymer and metal ions to be separated are placed in the ultrafiltration cell at a given $\mathrm{pH}$ and ionic strength. This mixture is then washed with metal-free solution that reproduces the same $\mathrm{pH}$ and ionic strength values. The fraction of polymer used was $>$ $100 \mathrm{kDa}$. The amount of polymer was $39.9 \mathrm{mg}(0.28 \mathrm{mmol})$. The solutions were prepared with twice-distilled water. The concentrations of metal ions (in $\mathrm{mg} / \mathrm{L})$ used in the ionic solution were: $10\left(\mathrm{Ca}^{2+}\right), 6\left(\mathrm{Mg}^{2+}\right), 7\left(\mathrm{Al}^{3+}\right), 50\left(\mathrm{~Pb}^{2+}\right)$, $16\left(\mathrm{Cu}^{2+}\right), 27\left(\mathrm{Ag}^{+}\right), 15\left(\mathrm{Ni}^{2+}\right), 15\left(\mathrm{Co}^{2+}\right), 16.5\left(\mathrm{Zn}^{2+}\right), 28\left(\mathrm{Cd}^{2+}\right)$, and $13\left(\mathrm{Cr}^{3+}\right)$.

The solutions were brought to $20 \mathrm{~mL}$ of total volume, and the $\mathrm{pH}$ was adjusted to $2.3,5.0$, and 8.0 by adding $0.1 \mathrm{M} \mathrm{HNO}_{3}$ or $0.1 \mathrm{M} \mathrm{NaOH}$ in separated experiments. The metal ions were studied at $\mathrm{pH}$ values where the metal ions are in the free state, avoiding the formation of species $\mathrm{M}(\mathrm{OH})^{\mathrm{n}+}$ and $\mathrm{M}(\mathrm{OH})_{\mathrm{n}}$. The $\mathrm{pH}$ value was measured by a $\mathrm{pH}$ meter $(\mathrm{H}$. Jürgen and $\mathrm{Co})$. All ultrafiltration studies were performed under a total pressure of 3.5 bar at room temperature. The total volume $(20 \mathrm{~mL})$ in the cell was kept constant and fractions of $20 \mathrm{~mL}$ were collected by filtration. Results of the metal ions uptake are systematically presented as the percentage of retention $\mathrm{R}(\%)$ versus the filtration factor $\mathrm{Z}$ (volume of filtrate / volume of the cell).

To study the removal of metal ions from aqueous solution using the washing method, two factors should be defined: (1) retention (R) that shows the fraction of metal ions remaining in the cell, and (2) filtering factor $(Z)$ showing the volume exchange ratio.

$$
\mathrm{R}=\left[\mathrm{M}_{\text {cell }}\right] /\left[\mathrm{M}_{\text {initial }}\right]
$$

where $\left[\mathrm{M}_{\text {cell }}\right]$ is the amount of metal ion that are retained in the cell and $\left[\mathrm{M}_{\text {initial }}\right]$ is the initial amount of metal ion. The filtration factor $(\mathrm{Z})$ is the ratio between the total permeate volume $\left(\mathrm{V}_{\mathrm{p}}\right)$ and the retentate volume $\left(\mathrm{V}_{\mathrm{r}}\right)$ :

$$
\mathrm{Z}=\mathrm{V}_{\mathrm{p}} / \mathrm{V}_{\mathrm{r}}
$$

2.3.2 Enrichment Method

The enrichment method determines the maximum retention capacity (MRC) of the polymer. A metal ion containing solution passes from the reservoir through the ultrafiltration cell filled with polymer solution. Both cell and reservoir solutions are adjusted to the same values of $\mathrm{pH}$ and ionic strength.

In this study, the concentrations of metal ions used in the ionic solution $(\mathrm{mg} / \mathrm{L})$ were $10\left(\mathrm{Ca}^{2+}\right), 1\left(\mathrm{Cu}^{2+}\right), 6\left(\mathrm{Mg}^{2+}\right)$, and $3\left(\mathrm{Al}^{3+}\right)$. Total permeate volume of the LPR system was set to $300 \mathrm{~mL}$.

\subsection{Sample Collection}

Prior to use, all materials were decontaminated with $40 \%$ of hydrochloric acid. River water samples were taken from Bío Bío river, located in VIII Region, Chile (between $36^{\circ} 45 \mathrm{~S}$ and $39^{\circ} \mathrm{S}$ ). The samples were collected in a Niski Sampling Bottled (model 1010-1.2 General Oceanics). Conductivity, $64.3 \mathrm{~ms}$ and $\mathrm{pH} 6.8$ were measured in situ. The samples were transferred to polypropylene bottles and transported to the laboratory. Then, they were filtered in a $0.45 \mathrm{~mm}$ cellulose acetate membrane. Finally, the samples were stored in polypropylene bottles at $5{ }^{\circ} \mathrm{C}$. The metal ions concentrations were determined by Electrothermal Atomic Absorption Spectrometry on a Unicam Solaar M5 series Atomic Absorption Spectrometer.

\section{RESULTS AND DISCUSSION}

\subsection{Characterization of PAAG}

3.1.1 Fourier transform-infrared (FT-IR) spectroscopy

To verify the presence of functional groups, the main fraction of the polymer was characterized by FT-IR (see Fig. 2). The spectra showed the following main characteristic absorption bands: $3397 \mathrm{~cm}^{-1} v_{-\mathrm{OH}}$ and $v_{\mathrm{NH}}$ wide; $3075 \mathrm{~cm}^{-1} \mathrm{v}_{\mathrm{CH} 2} ; 2932 \mathrm{~cm}^{-1} v_{\mathrm{CH}} ; 1745 \mathrm{~cm}^{-1} v_{\mathrm{C}=\mathrm{O}}$ of carboxylic group; $1662 \mathrm{~cm}^{-1}$ $v_{\mathrm{C}=\mathrm{O}}$ band of amide I; $1535 \mathrm{~cm}^{-1} v_{\mathrm{N}-\mathrm{C}=\mathrm{O}}$ symetric band amide II; $1447 \mathrm{~cm}^{-1} \delta$ ip ${ }_{-\mathrm{OH}} ; 1095 \mathrm{~cm}^{-1} \mathrm{v}_{\mathrm{C}-\mathrm{O} \text {. }}$

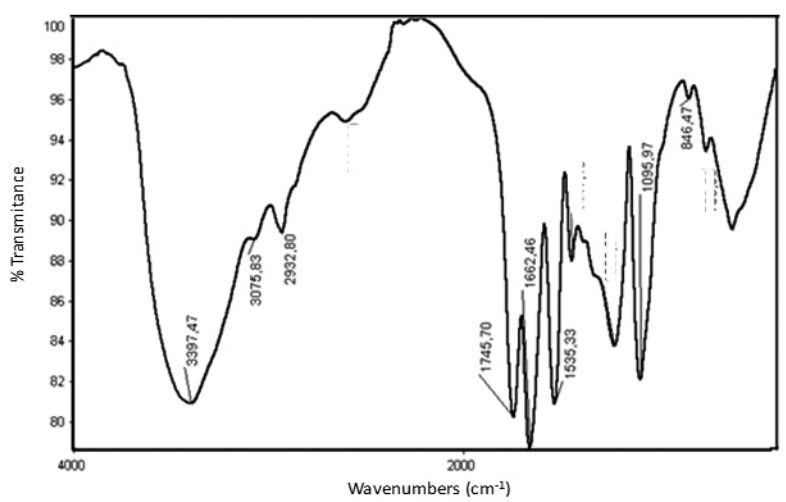

Figure 2. Fourier transformed-infrared spectra in $\mathrm{KBr}$ pellet of PAAG.

\subsubsection{Potentiometric titration}

With the potentiometric titration is possible to determine the experimental intrinsic acid dissociation constant, $\mathrm{pKa}$, of the studied molar mass fraction of PAAG. Thereby, it is possible to establish whether the carboxylic acid group is mostly dissociated or associated with a particular $\mathrm{pH}$ and to relate this with the obtained retention profiles.

The figure 3 shows the potentiometric curve of poly(2-acrylamidoglycolic acid). At the lowest $\mathrm{pH}$, the polymer was not dissociated because the degree of dissociation depends on the environment. The acid-base titration shows the turning point of the weak polyacid corresponding to the dissociation of the carboxylic acid to carboxylate. The intrinsic pKa when $\alpha$ approach to zero corresponds to 4.37 .

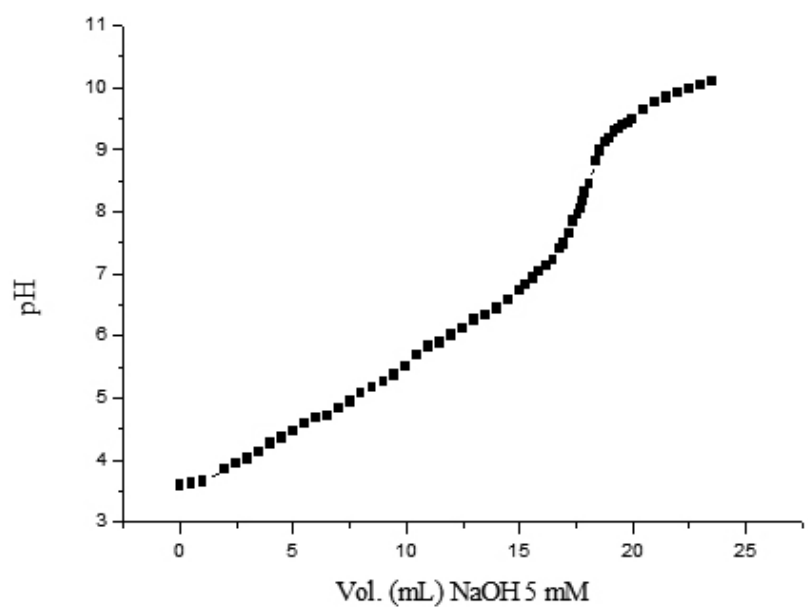

Figure 3. Potentiometric titration of $5 \mathrm{mM}$ PAAG with $5 \mathrm{mM} \mathrm{NaOH}$.

\subsection{Characterization of Bío Bío river water samples}

Some information about the $\mathrm{pH}$ and conductivity of the samples, both in situ and after filtered and charged with metal in the laboratory, are detailed on table 1.

Table 1. pH and conductivity of the samples.

\begin{tabular}{|c|c|c|c|}
\hline $\mathrm{pH}$ in situ & $\begin{array}{c}\text { Conductivity }(\mu \mathrm{S}) \\
\text { in situ }\end{array}$ & $\mathrm{pH}$ filtred water & $\begin{array}{c}\mathrm{pH} \text { of charged } \\
\text { water }\end{array}$ \\
\hline 6.8 & 64.3 & 7.14 & 5.78 \\
\hline
\end{tabular}


Before to remove metal ions from Bío Bío river water, the samples were charged with additional concentrations of metal ions. Table 2 describes the natural concentrations of metal ions in the river samples and the concentration used on the removal experiments. The highest natural concentrations correspond to calcium, magnesium and aluminum, meanwhile copper is the lowest.

Table 2. Natural concentration of metal ions on Bío Bío river samples and concentration of metal ions on samples charged

\begin{tabular}{|c|c|c|}
\hline Metal Ions & $\begin{array}{c}\text { Natural concentration }(\mu \mathrm{g} / \mathrm{L}) \\
\text { on river samples }\end{array}$ & $\begin{array}{c}\text { Concentration }(\mathrm{mg} / \mathrm{L}) \text { on } \\
\text { charged samples }\end{array}$ \\
\hline $\mathrm{Cu}^{2+}$ & 0.52 & 1.0 \\
\hline $\mathrm{Ca}^{2+}$ & 3000 & 12.0 \\
\hline $\mathrm{Mg}^{2+}$ & 2000 & 8.0 \\
\hline $\mathrm{Al}^{3+}$ & 50 & 3.0 \\
\hline
\end{tabular}

3.3 Effect of pH on metal ions removal by washing method

Firstly, we determined if the membrane interacts with the metal ions at different $\mathrm{pH}$ values. This experiment is called blank. The blanks were performed using different membranes of polyethersulfone with sizes of molecular weight exclusion of $10 \mathrm{kDa}$ and $3 \mathrm{kDa}$, in equivalent conditions to polymer-metal experiments. If the membrane is not involved in the retention, the concentration of ions in the filtrate must be equal to the concentration of ions inside the cell. The results show no interaction of metal ions with the membrane, the ions are eluted completely through it for all $\mathrm{pH}$ values used.

The fraction of the polymer used for the removal of metal ions is greater than $100 \mathrm{kDa}$, it was the major fraction obtained from the synthesis of PGGA.

The study of the influence of $\mathrm{pH}$ on the metal ions removal was first analyzed by washing method. Observing PAAG structure is meant that the carboxylic acid sites can interact with various metal ions tested. It is the dissociation of the terminal carboxylic acid group is strongly related with $\mathrm{pH}$ values that we are studying. In fact, previously, we have determined the pKa of PAAG, giving a value of 4.37. Taking this value can be related retention values with acid-base balance of the polyacid. Varying $\mathrm{pH}$ conditions the polymer is mainly protonated at $\mathrm{pH}$ below 4.37 and at $\mathrm{pH}$ values above than 4.37 is mainly deprotonated and polyanionic species exist.

The figure 4 shows the removal metal ions from ionic mixture. The selective retention $(100 \%)$ of $\mathrm{Al}^{3+}$ was obtained at $\mathrm{pH} 2.36$ in our experimental conditions.

These aluminum ions are displacing the protons attached to the carboxylate group to form in the case of a complex aluminum as shown in the figure 5 .

The differences in the complexing ability of the polymer respect to the metal ions at acid $\mathrm{pH}(2.36)$, may be attributed primarily to structural moieties, a large ratio of surface area to volume can contribute to some of the unique properties of the complex aluminum ions, and a high stability of the PAAG forming complex with $\mathrm{Al}^{3+}$. The interconnected carboxylic acid/ carboxylate groups containing domains are highly polar and can be swollen by water. Therefore, the interconnected functional groups containing domains can provide a good diffusion path for $\mathrm{Al}^{3+}$ through the matrix polymeric.

The removal of $\mathrm{Ag}(\mathrm{I})$ and divalent ions was minimum at $\mathrm{pH} 2.36$, however, it was maximum for all the metal ions at $\mathrm{pH} 5$ and 8 . This fact can be explained by the dissociation of the carboxylic group of the PAAG at theses $\mathrm{pH}$ values and the polymer-metal complex formation.

The polymer metal complexing capacity depends not only on the nature of ligand groups but also on metal ion accessibility and stability of the polymer complex [24].

3.3 Metal ions removal from natural waters by enrichment method

Previously, we have studied removal of arsenic from the Camarones river by using water-soluble polymers based on quaternary ammonium groups. The water-soluble polymer showed a high performance $(100 \%)$ for the first $Z$ values and then decreased up to $16 \%$ for $Z=10$ [25]. It was probably due to the higher amount of salts of the Camarones river samples [26].

In the present work, the maximum retention capacity of some metal ions by PAAG was studied by enrichment method using water of Bío Bío river containing metal ions for $\mathrm{Z}=15$ at $\mathrm{pH} 2.36$ for $\mathrm{Al}^{3+}$ and $\mathrm{pH} 7.14$ for $\mathrm{Cu}^{2+}, \mathrm{Ca}^{2+}$ and $\mathrm{Mg}^{2+}$. The figure 6 shows the results obtained as concentration of metal ions in the filtrate versus volume of the filtrates. In the case of $\mathrm{Ca}^{2+}$ and $\mathrm{Mg}^{2+}$, it can be seen an increase in the metal ion concentration in the filtrate until it reaches a maximum concentration, the saturation volume of $300(\mathrm{~mL})$ and $120(\mathrm{~mL})$; respectively. In the case of $\mathrm{Cu}^{2+}$ and $\mathrm{Al}^{3+}$, they do not saturate the polymer, therefore, it can be determined the retention percentage.
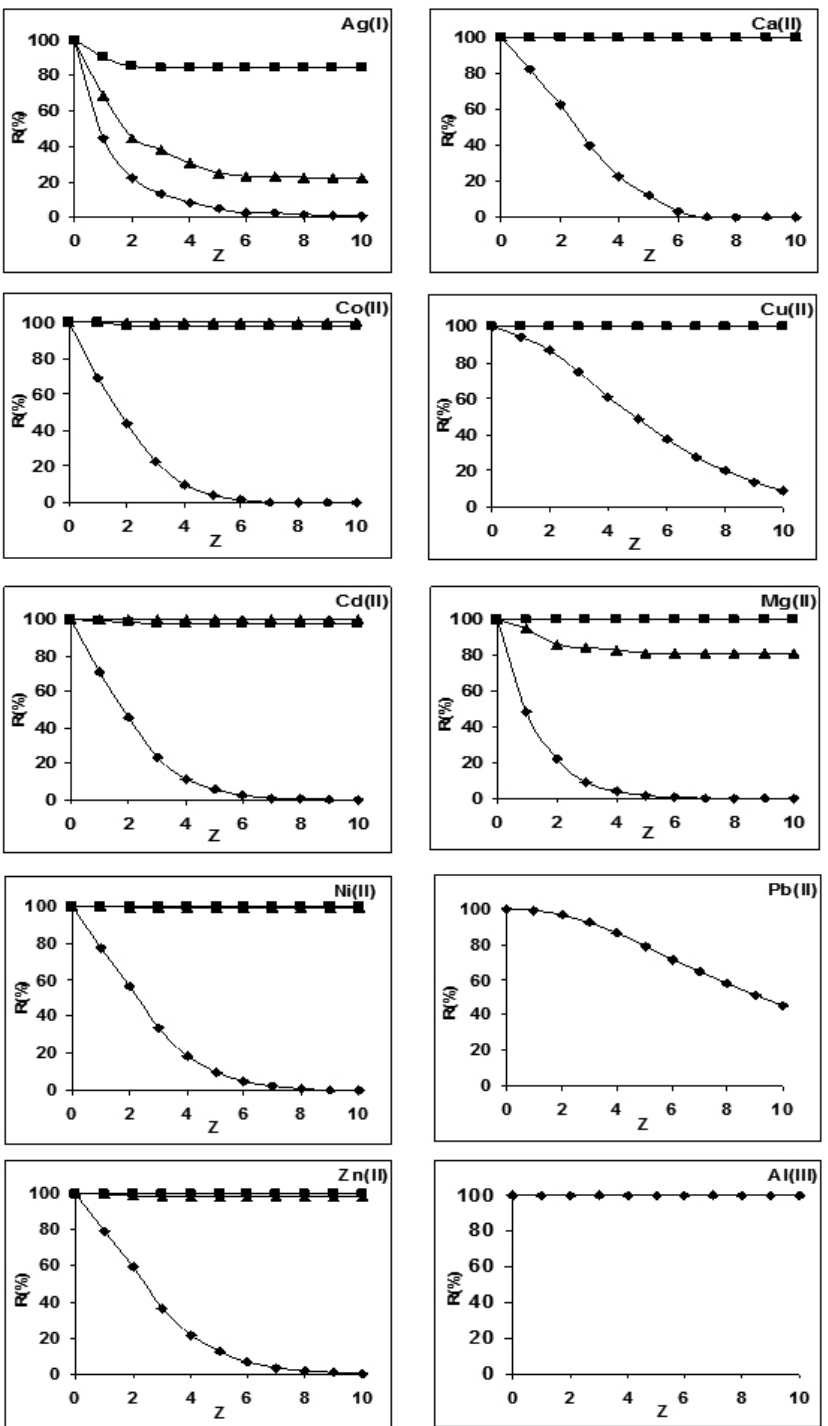

Figure 4. Retention profiles of metal ions from ionic mixture by PAAG

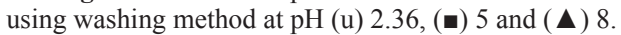

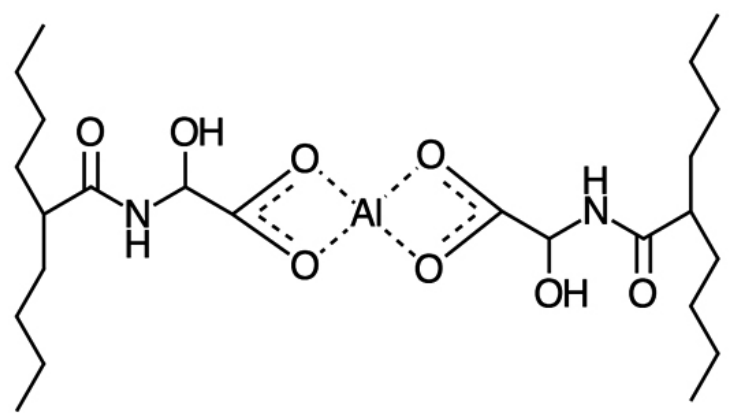

Figure 5. Interaction of the carboxylic acid groups from both monomer units with $\mathrm{Al}^{3+}$ 

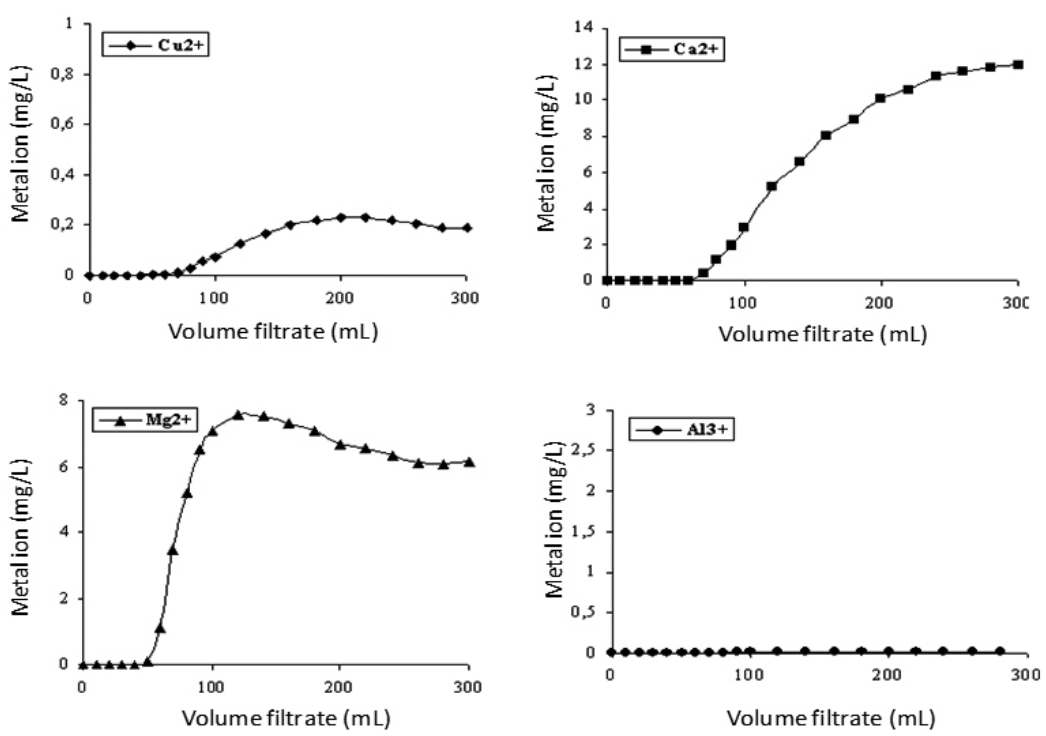

Figure 6. Metal ion concentration in the filtrate versus volume of filtrate using PAAG as an extracting reagent.

The retention of metal ions by the PAAG using the enrichment method shows retention values over $55 \%$. This indicates that the polymer interacts with the metal ions even using a matrix of river water. Moreover, in this study the retention behavior shows no significant difference comparing the water of river and double distilled water.

Figure 7 shows the retention rates. In the case of $\mathrm{Cu}^{2+}$ and $\mathrm{Al}^{3+}$, the polymer is not saturated and has high retention values by forming coordination bonds. The high retention percentages for $\mathrm{Al}^{3+}$ ion in the cases studied indicate that PAAG could be used as a removal reagent of $\mathrm{Al}^{3+}$ ions.

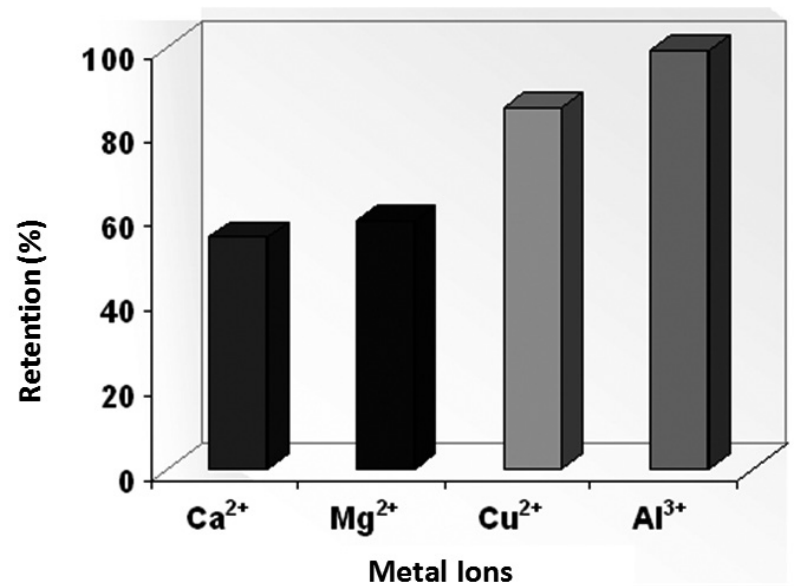
PAAG

Figure 7. Retention percentages metal ions from Bío Bío river water by

\section{CONCLUSIONS}

The synthesized water-soluble PAAG showed the main characteristic absorption FTIR bands corresponding to the functional groups of the polymer. The intrinsic pKa of PAAG corresponds to 4.37 , it was determined by potentiometric titration.

The removal of metal ions was studied by LPR using the washing and enrichment method. By washing method, the selective retention (100\%) of $\mathrm{Al}^{3+}$ was obtained at $\mathrm{pH} 2.36$ under current experimental conditions. The removal of $\mathrm{Ag}(\mathrm{I})$ and divalent ions was maximum for all the metal ions at $\mathrm{pH} 5$.

The maximum retention capacity of some metal ions by PAAG was studied by enrichment method using water of Bio-Bio River containing metal ions. The high retention percentages for $\mathrm{Al}^{3+}$ ion in the cases studied indicated that PAAG could be used as removal reagent for $\mathrm{Al}^{3+}$ ions.

\section{ACKNOWLEDGMENTS}

The authors thanks to FONDECYT Grant No 11140324 REDOC N ${ }^{\circ}$ UC0 1202 and CIPA CONICYT REGIONAL/CIPA/R08C1002.

\section{REFERENCES}

1. B. Freedman, T. C. Hutchinson, Sources of Metal and Elemental Contamination of Terrestrial Environments, Effect of Heavy Metal Pollution on Plants, Pollution Monitoring Series Volume 2, Springer Netherlans, 1981; pp 35-94.

2. E. Laws, Metals. Aquatic Pollution. An Introductory Text. John Wiley \& Sons, Inc. New York, 1993; 383-396.

3. D. Connell and G. Miller, Chemistry and Ecotoxicology of Pollution. John Wiley \& Sons, N.Y. 1984.

4. T. Duxbury, Microbes and heavy metals: and ecological overview. Microbiol. Sci. 3 330, (1986)

5. G. Gadd, Microbiol. Lett. 100, 204, (1992)

6. T. Clarkson. Environ. Health Persp. 103, 9, (1995)

7. A. Denizli, R. Say, E. Piskin, React. Funct. Polym. 55, 99, (2003)

8. R.A. Yokel, D.D. Allen, D.C. Ackley, J. Inorg. Biochem. 76, 127, (1999)

9. T. Peder Flaten, Brain Res. Bull. 55, 187, (2001)

10. M. Andac, E. Ozyapi, S. Senel, R. Say, A. Denizli, Ind. Eng. Chem. Res. 45, 1780, (2006)

11. E. Drioli, E. Fontananova, Chem. Eng. Res. Des. 82, 1557, (2004)

12. B.L. Rivas, E.D. Pereira, M, Palencia, J. Sánchez, Prog. Polym. Sci. 36, 294, (2011)

13. J. Sanchez, B.L. Rivas, E. Nazar, M. Bryjak, N. Kabay, J. Appl. Polym. Sci. 162, 1541, (2013)

14. B.L. Rivas, E. Pereira, J. Paredes, J. Sanchez, Polym. Bull. 69, 1007 (2012)

15. B.L. Rivas, S. Hube, J. Sanchez, E. Pereira, Polym. Bull. 69, 881, (2012)

16. L. Toledo, B.L. Rivas, B.F. Urbano, J. Sánchez, Sep. Purif. Technol. 103 $1,(2013)$

17. B.L. Rivas, E. Pereira, R. Cid, J. Appl. Polym. Sci. 95, 1091, (2005)

18. B.L.Rivas, I. Moreno-Villoslada, J. Membrane Sci. 178, 165, (2000)

19. B.L. Rivas, E.D. Pereira, Bol. Soc. Chil. Quim. 45, 165, (2000)

20. K.E. Geckeler, R.N. Zhou, B.L. Rivas, Angew. Makromol. Chem. 197, 107, (1992)

21. B.L Rivas, N. Schiappacasse, E. Pereira, I. Moreno-Villoslada, Polymer 45, 1771, (2004)

22. B.L. Rivas, A.E. Maureira, Eur. Polym. J. 44, 523, (2008) 
23. Bernabé L. Rivas, Antonio Maureira, Inorg. Chem. Commun. 10, 151, (2007)

24. O.G. Marambio, J. Sánchez, G.C. Pizarro, M. Jeria-Orell, B.L. Rivas, Polym. Bull. 65, 701, (2010)
25. J. Sánchez, B.L. Rivas, Desalination 270, 57, (2011)

26. L. Cornejo, H. Lienqueo, M. Arenas, J. Acarpi, D. Contreras, J. Yáñez, H.D. Mansilla, Environ. Pollut. 156, 827, (2008) 